\title{
A comparison between secretin alone and sequential and simultaneous secretin and cholecystokinin administration in the assessment of pancreatic function $^{1}$
}

\author{
JONATHAN CLAIN, SIMMY BANK, G. O. BARBEZAT, B. H. NOVIS, AND I. N. MARKS \\ From the Gastrointestinal Clinic, Groote Schuur Hospital, and the Department of Medicine, University of \\ Cape Town, Cape Town, South Africa
}

SUMmary Pancreatic volume, bicarbonate and enzyme secretion were studied after sequential and after simultaneous secretin and cholecystokinin (CCK) stimulation and the results compared. No statistical difference between sequential or simultaneous stimulation was noted. A comparison of secretin alone with simultaneous secretin plus cholecystokinin stimulation showed that the combination yielded a significantly higher trypsin concentration.Volume and bicarbonate were unchanged.

Although secretin alone has been used as a hormonal stimulus for the evaluation of pancreatic function (Lagerlöf, 1942; Dreiling and Hollander, 1948), most centres now use cholecystokinin (CCK) in addition, in the belief that the diagnostic value of pancreatic enzyme estimation is greater with the use of both hormones. There is, however, no uniformity in the literature regarding the sequence in which secretin and cholecystokinin are administered.

This study was undertaken to compare sequential and simultaneous hormone administration, and also to establish whether secretin alone was comparable to secretin combined with cholecystokinin as a stimulus to pancreatic secretion.

\section{Material and Methods}

Twenty-five patients with suspected pancreatic disease, randomized into three groups, were studied. Each patient volunteered to undergo two 80-minute pancreatic function tests, in tandem, the first test being separated from the second by an interval of 30 minutes.

Submaximal doses of secretin (GIH lu/kg or Boots $2 \mathrm{u} / \mathrm{kg}$ ) and cholecystokinin (GIH or Boots $1.5 \mathrm{u} / \mathrm{kg}$ ) were given by slow intravenous injection.

${ }^{1}$ This work was supported by the Medical Research Council of South Africa.

Received for publication 10 July 1974.
Either Boots or GIH hormones were used in any one patient. Studies were randomized in the following way (see fig).

\section{GROUP 1}

Five patients received secretin followed 60 minutes later by cholecystokinin in both tests.

\section{GROUP 2}

Five patients received secretin followed 60 minutes later by cholecystokinin in the first test, and simultaneous secretin and cholecystokinin in the second test. The order of the tests was reversed in a further five patients.

\section{GROUP 3}

Five patients received secretin followed by $\mathrm{CCK}$ at $60 \mathrm{~min}$ in the first test, and CCK followed by secretin at 20 minutes in the second test. In a further five patients the order of the tests was reversed.

The pancreatic function tests were carried out as previously described from this unit (Bank, Marks, Moshal, Efron, and Silber, 1963). The patients were fasted overnight, and a radioopaque nasogastric tube (Rusch no. 14 or 16) was positioned fluoroscopically at the junction of the second and third parts of the duodenum. Eight 10-minute samples were collected on ice by constant mechanical aspiration, alternating every five minutes with manual syringing of the tube. A second tube, positioned fluoroscopically in the most dependent 
group. 1
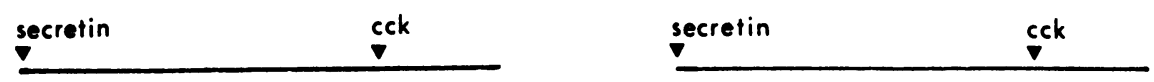

(5)

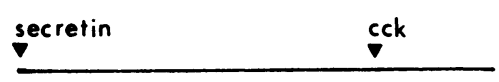

secretin

cck

group 2

secretin

(5)

cck

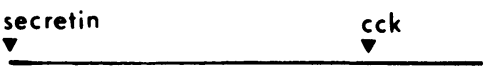

(5)

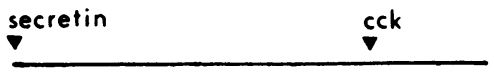

cck secretin

group 3

(5)
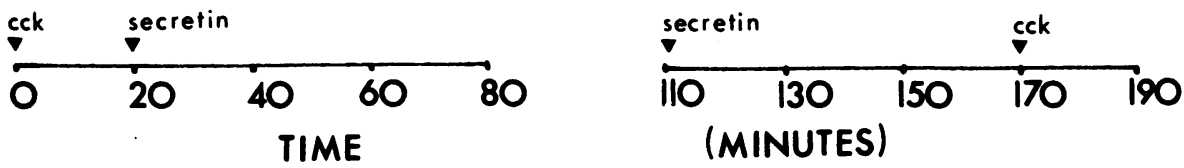

Fig Sequence of administration of secretin and CCK in the three groups. () denotes the number of cases.

position in the stomach, excluded gastric juice from the duodenum.

The 80-minute volume output was recorded and the bicarbonate concentration estimated by the micro van Slyke method. Amylase (Pimstone, 1964), trypsin and chymotrypsin (Schwert and Takenaka, 1955), and lipase (Weber, 1965) concentrations were measured. The unpaired Student's $t$ test was used to calculate statistical significance and the least square method to calculate the correlation coefficient (r).

\section{Results}

The results of the tandem tests are shown in tables I, II, and III. Table I has confirmed our previous data concerning the similarity between two 80- minute secretin-CCK tests when carried out after an interval of 30 minutes (Bock, Bank, Marks, Moshal, Groll, Loxton, and Dines, 1968). Any variation in pancreatic response between tests can therefore be attributed to differences in the sequence of administration of secretin and CCK.

In groups 2 and 3 (tables II and III) the order of performing the tests was unimportant, so results of studies done the same way were pooled, giving 10 in each group. Volume, $\mathrm{HCO}_{3}$, and enzyme secretion were the same whether secretin was followed by CCK or CCK followed by secretin or the two hormones were given simultaneously. In addition, the correlation coefficient ( $r$ ) was significant within the $95 \%$ confidence limits between the two tests in group 2 with respect to volume, $\mathrm{HCO}_{3}$, and all the enzymes, and between the two tests in group 3 with

\begin{tabular}{|c|c|c|c|c|}
\hline & Mean Test $1 \pm S E M$ & Mean Test $2 \pm S E M$ & $\mathbf{P}$ & $r$ \\
\hline $\begin{array}{l}\text { Volume (ml/80 min) } \\
\text { Bicarbonate (m-equiv/l) } \\
\text { Amylase (u/ml) } \\
\text { Trypsin (u/ml) } \\
\text { Chymotrypsin (u/ml) } \\
\text { Lipase (IU/l) }\end{array}$ & $\begin{aligned} 293 & \pm 47 \\
81 & \pm 3.81 \\
6.25 & \pm 1.47 \\
1842 & \pm 229 \\
1194 & \pm 233 \\
395 & \pm 60\end{aligned}$ & $\begin{aligned} 311 & \pm 52 \\
83 & \pm 4 \cdot 97 \\
5 \cdot 28 & \pm 1 \cdot 11 \\
2242 & \pm 224 \\
1124 & \pm 119 \\
402 & \pm 61\end{aligned}$ & $\begin{array}{l}>0.7 \\
>0.6 \\
>0.6 \\
>0.2 \\
>0.8 \\
>0.9\end{array}$ & $\begin{array}{l}0.97 \\
0.88 \\
0.99 \\
0.81 \\
0.76 \\
0.84\end{array}$ \\
\hline
\end{tabular}

Table I Sequential secretin and CCK in both tests in group 1 (five cases) 


\begin{tabular}{lcccc}
\hline & Mean Test 1 \pm SEM & Mean Test 2 \pm SEM & P & $r$ \\
\hline Volume (ml/80 min) & $275 \pm 46$ & $242 \pm 39$ & $>0.5$ & 0.88 \\
Bicarbonate (m-equiv/l) & $70 \pm 4.75$ & $60 \pm 5.09$ & $>0.6$ & 0.80 \\
Amylase (u/ml) & $5.27 \pm 1.25$ & $5.92 \pm 1.44$ & $>0.7$ & 0.92 \\
Trypsin (u/ml) & $1886 \pm 318$ & $1851 \pm 233$ & $>0.9$ & 0.86 \\
Chymotrypsin (u/ml) & $775 \pm 204$ & $827 \pm 165$ & $>0.8$ & 0.85 \\
Lipase (IU/l) & $329 \pm 83$ & $324 \pm 74$ & $>0.95$ & 0.91 \\
\hline
\end{tabular}

Table II Sequential secretin and CCK in the first test followed by simultaneous administration in the second test in group 2 (10 cases)

\begin{tabular}{lcccc}
\hline & Mean Test 1 \pm SEM & Mean Test 2 \pm SEM & P & $r$ \\
\hline Volume (ml/80 min) & $205 \pm 19$ & $181 \pm 21$ & $>0.4$ & 0.68 \\
Bicarbonate (m-equiv/l) & $63 \pm 8.36$ & $67 \pm 6.78$ & $>0.6$ & 0.95 \\
Amylase (u/ml) & $3.93 \pm 0.77$ & $3.97 \pm 0.76$ & $>0.88$ \\
Trypsin (u/ml) & $2458 \pm 386$ & $2938 \pm 441$ & 0.75 \\
Chymotrypsin (u/ml) & $1173 \pm 197$ & $1412 \pm 265$ & $>0.4$ & 0.82 \\
Lipase (IU/l) & $367 \pm 69$ & $386 \pm 61$ & $>0.8$ & 0.82 \\
\hline
\end{tabular}

Table III Sequential secretin and CCK in the first test followed by sequential CCK and secretin in the second test in group 3 (10 cases)

\begin{tabular}{|c|c|c|c|c|c|c|c|c|c|c|c|c|c|}
\hline & \multicolumn{2}{|c|}{$\begin{array}{l}\mathrm{Vol} \\
(\mathrm{ml} / 60 \mathrm{~min})\end{array}$} & \multicolumn{2}{|c|}{$\begin{array}{l}\text { Bicarbonate } \\
\text { (m-equiv } / l)\end{array}$} & \multicolumn{2}{|c|}{$\begin{array}{l}\text { Amylase } \\
(u / m l)\end{array}$} & \multicolumn{2}{|c|}{$\begin{array}{l}\text { Trypsin } \\
(u / m l)\end{array}$} & \multicolumn{2}{|c|}{$\begin{array}{l}\text { Chymotrypsin } \\
(u / m l)\end{array}$} & \multicolumn{2}{|c|}{$\begin{array}{l}\text { Lipase } \\
(I U / I)\end{array}$} & \multirow[t]{2}{*}{ Diagnosis } \\
\hline & $S$ & $S+C C K$ & $S$ & $S+C C K$ & $S$ & $S+C C K$ & $S$ & $S+C C K$ & $S$ & $S+C C K$ & $S$ & $\overline{S+C C K}$ & \\
\hline $\begin{array}{r}1 \\
2 \\
3 \\
4 \\
5 \\
6 \\
7 \\
8 \\
9 \\
10\end{array}$ & $\begin{array}{r}200 \\
136 \\
608 \\
186 \\
157 \\
119 \\
265 \\
95 \\
88 \\
179\end{array}$ & $\begin{array}{l}246 \\
164 \\
524 \\
166 \\
234 \\
125 \\
161 \\
152 \\
158 \\
139\end{array}$ & $\begin{array}{l}51 \\
74 \\
57 \\
87 \\
90 \\
94 \\
74 \\
62 \\
53 \\
75\end{array}$ & $\begin{array}{l}68 \\
80 \\
57 \\
83 \\
89 \\
83 \\
66 \\
48 \\
40 \\
61\end{array}$ & $\begin{array}{r}3.31 \\
4.48 \\
0.68 \\
11.91 \\
0.65 \\
2.73 \\
9.63 \\
3.08 \\
2.71 \\
9.49\end{array}$ & $\begin{array}{r}1.40 \\
8.92 \\
1.00 \\
8.62 \\
0.36 \\
9.95 \\
13.25 \\
3.46 \\
2.86 \\
12.07\end{array}$ & $\begin{array}{r}498 \\
1442 \\
917 \\
2584 \\
394 \\
1388 \\
1292 \\
625 \\
1313 \\
2896\end{array}$ & $\begin{array}{r}753 \\
3230 \\
1199 \\
2500 \\
1875 \\
4000 \\
2979 \\
1417 \\
1167 \\
3771\end{array}$ & $\begin{array}{r}146 \\
688 \\
167 \\
2042 \\
303 \\
167 \\
562 \\
219 \\
396 \\
1188\end{array}$ & $\begin{array}{r}167 \\
1521 \\
250 \\
1688 \\
443 \\
2000 \\
937 \\
729 \\
542 \\
2000\end{array}$ & $\begin{array}{r}73 \\
594 \\
172 \\
581 \\
188 \\
154 \\
183 \\
71 \\
149 \\
644\end{array}$ & $\begin{array}{l}123 \\
443 \\
271 \\
618 \\
204 \\
378 \\
328 \\
154 \\
110 \\
802\end{array}$ & $\begin{array}{l}\text { Chronic pancreatitis } \\
\text { Diabetes mellitus } \\
\text { Cirrhosis, pancreatitis } \\
\text { Normal } \\
\text { Coeliac disease } \\
\text { Acute pancreatitis } \\
\text { Acute pancreatitis } \\
\text { Calcific pancreatitis } \\
\text { Chronic pancreatitis } \\
\text { Normal }\end{array}$ \\
\hline Mean & 203 & 206 & 72 & 67 & $4 \cdot 87$ & $6 \cdot 19$ & 1335 & 2289 & 588 & 1028 & 281 & 393 & \\
\hline $\begin{array}{l}\text { SEM } \\
\mathbf{P} \\
\mathbf{r}\end{array}$ & $\begin{array}{r} \pm 48 \\
>\end{array}$ & $\begin{array}{l}0.95^{ \pm 37} \\
0.92\end{array}$ & $\begin{array}{r}5 \cdot 01 \\
>\end{array}$ & $\begin{array}{l}5 \cdot 01 \\
.5 \\
.80\end{array}$ & $\begin{array}{r}1 \cdot 26 \\
>0 \\
0\end{array}$ & $\begin{array}{l}0.54 \\
0.75^{1.54}\end{array}$ & $\begin{array}{r}264 \\
<C\end{array}$ & $\begin{array}{l}369 \\
0.05 \\
0.63\end{array}$ & 191 & $\begin{array}{l}226 \\
0 \cdot 1 \\
0 \cdot 58\end{array}$ & 72 & $\begin{array}{l}93 \\
0.94\end{array}$ & \\
\hline
\end{tabular}

Table IV 60-Minute secretin compared with 60-minute secretin- and CCK-stimulated secretion

respect to $\mathrm{HCO}_{3}$ and all the enzymes. In individual patients tandem tests showed remarkably reproducible results.

Data were extracted from test group 2 (see fig), enabling a comparison in 10 patients between 60 minute secretin stimulation alone and 60-minute combined stimulation with secretin and CCK (table IV). The mean volume output and bicarbonate concentrations were similar in the two tests, but the addition of CCK affected the mean enzyme concentration. The latter was higher for all four enzymes in the secretin/CCK test, although this was only significant for trypsin concentration $(P<0.05)$.

\section{Discussion}

In tests of pancreatic function CCK has previously been given before secretin (Dreiling and Janowitz, 1961; Sun, 1963), with secretin (Zieve, Silvis, Mulford, and Blackwood, 1964), and after secretin (Marks and Tompsett, 1958; Burton, Evans, Harper, Howat, Oleesky, Scott, and Varley, 1960; Bank et al, 1963). Most clinical investigators administered the hormones by a single intravenous bolus rather than as a constant infusion and the same mode of administration was employed in the present study. There was no statistical difference between the 80-minute tests comparing secretin followed by CCK, CCK followed by secretin, or secretin and CCK given together. A 60-minute comparison between secretin alone and secretin plus CCK stimulation (table IV) was prompted by the fact that some workers use secretin alone in assessing pancreatic function. Secretin, although a weak stimulant of enzyme 
secretion (Wormsley, 1969), has a recognized washout effect which in some patients may result in an appreciable enzyme response. A comparison was therefore made between the enzyme response to secretin alone and to a combination of secretin/CCK to assess whether the latter produces a significantly higher response. The volume output was not statistically different, although the effect of CCK on gallbladder contraction might have been expected to influence volume output. Bicarbonate concentration, known to be slightly enhanced by the addition of CCK (Wormsley, 1969), did not differ in the two tests. The four enzymes measured all markedly increased on the addition of CCK, although this only assumed significance for trypsin $(P<0.05)$. This, together with their failure to produce a positive correlation coefficient for trypsin $(r=0.63)$ and chymotrypsin $(r=0.58)$, indicates that secretin alone is incapable of producing an enzyme response comparable to secretin and CCK.

Cholecystokinin, therefore, increases the concentration of enzymes in the pancreatic juice, but its time of administration in relation to secretin is not critical in the assessment of pancreatic function.

\section{References}

Bank, S., Marks, I. N., Moshal, M. G., Efron, G., and Silber, W. (1963). The pancreatic-function test: method and normal values. S. Afr. med. J., 37, 1061-1066.

Bock, O. A. A., Bank, S., Marks, I. N., Moshal, M. G., Groll, A. Loxton, A., and Dines, M. (1968). Effect of propantheline bromide and pipenzolate bromide upon exocrine pancreatic secretion. Gastroenterology, 55, 199-203.

Burton, P., Evans, D. G., Harper, A. A., Howat, H. T., Oleesky, S. Scott, J. E., and Varley, H. (1960). A test of pancreatic function in man based on the analysis of duodenal contents after administration of secretin and pancreozymin. Gut, 1, 111-124.

Dreiling, D. A., and Janowitz, H. D. (1962). The measurement of pancreatic secretory function. In The Exocrine Pancreas (Ciba Foundation Symposium), edited by A. V. S. de Reuck and M. P. Cameron, pp. 225-258. Churchill, London.

Lagerlöf, H. O. (1942). Pancreatic function and pancreatic disease studied by means of secretin. Acta med. scand., Suppl. 128.

Marks, I. N., and Tompsett, S. L. (1958). The diagnosis of pancreatic disease. Quart. J. Med., 27, 431-461.

Pimstone, N. R. (1964). [A (study of the starch-iodine complex: a modified colourimetric micro determination of amylase in biological fluids. Clin. Chem., 10, 891-906.

Schwert, G. W., and Takenaka, Y. (1955). A spectrophotometric determination of trypsin and chymotrypsin. Biochim. biophys. Acta (Amst.), 16, 570-575.

Sun, D. C. H. (1963). Normal values for pancreozymin-secretin test. Gastroenterology, 44, 602-606.

Weber, H. (1965). Mikromethode zur bestimmung der Pankreaslipase imserum. Dtsch. med. W'schr., 90, 1170-1174.

Wormsley, K. G. (1969). A comparison of the response to secretin, pancreozymin and a combination of these hormones in man. Scand. J. Gastroent., 4, 413-417.

Zieve, L., Silvis, S. E., Mulford, B., and Blackwood, W. D. (1964). Secretion of pancreatic enzymes. 1. Response to secretin and pancreozymin. Amer. J. dig. Dis., 11, 671-684. 